\title{
The Effect of Malnutrition on Mortality in Hospitalized Children
}

\section{ISSN: 2576-9200}

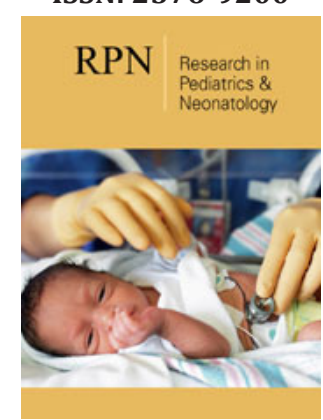

${ }^{* 1}$ Corresponding author: Aida $\mathrm{H} \mathrm{Al}-$ Sadeeq, Department of Pediatric, Yemen

Submission: 毕June 24, 2019

Published: 㳑August 28, 2019

Volume 3 - Issue 5

How to cite this article: Aida $\mathrm{H}$. AlSadeeq. The Effect of Malnutrition on Mortality in Hospitalized Children. Res Pediatr Neonatol. 3(5).RPN.000571.2019. DOI: $10.31031 /$ RPN.2019.03.000571

Copyright@ Aida H. Al-Sadeeq, This article is distributed under the terms of the Creative Commons Attribution 4.0 International License, which permits unrestricted use and redistribution provided that the original author and source are credited.

\author{
Aida H. Al-Sadleeq* \\ Department of Pediatric, Yemen
}

\section{Introduction}

Malnutrition responsible for $45 \%$ of deaths among children younger than 5 years in lowand middle-income countries [1,2]. Many studies have reported the individual associations of stunting, wasting, and underweight with mortality [3], However, estimates of the effects of individual anthropometric indicators overlook the fact that multiple deficits may occur simultaneously, especially because all deficits are associated with poverty, poor dietary intake, and infectious diseases [4,5]. This study conducted describe the frequency of undernutrition and to evaluate which types of combined anthropometric deficits carry an increased risk of mortality.

\section{Patients and Methods}

A retrospective observational study, conducted in the therapeutic feeding center (TFC) of Al-Sadaka General Teaching Hospital (GTH), Aden, Yemen, included severely malnourished children (SAM) aged 2-59 months, who were admitted from September 2015 to February 2016. Children with generalized edema were excluded. All enrolled children were grossly devoid of any deformities and had no chronic ill conditions.

\section{Data Collection \& Management}

The following data obtained from patient's files on the first day of admission: age, weight $(\mathrm{kg})$, length/height $(\mathrm{cm})$. In addition, death outcome, co-morbidities among death cases, and the duration of hospitalization till the time of death were recorded. Patients were categorized into two age groups (2-23m, and 24-59m). The 2006 WHO Multicenter Growth Reference Study [6] was used to assess every child's z-scores of length/heights-for-age, weight-forlength/height, and weight-for-age.

\section{Data Analysis}

Data were analyzed using SPSS for Windows (Version 20.0). A chi-square analysis was performed to determine the significant of age difference. A p-value of less than 0.05 was considered to be statistically significant.

\section{Results}

A total 299 SAM were admitted during the study period, included 266 (89.0\%) SAM less than 2 years and 33 (11.0\%) SAM more than 2 years. Among the two-age group, more than third of SAM were also underweight. Stunting seen more among older than 2-year SAM (51.5\%) compared to younger than 2-year SAM, however, the difference was statistically insignificant, (Table $1 \& 2$ ). Presents some of the background characteristics children who died during management of SAM. The majority SAM who died were $6-23 \mathrm{~m}$ old, admitted for diarrhea, and were having severe triple deficits (wasting, underweight, stunting) and died in the first three days of admission.

\section{Discussion, Conclusion \& Recommendation}

The study provides evidence that simultaneous presence of multiple anthropometric deficits heightened risk of mortality among malnourished patients, this finding is consistent with a recent review of 10 prospective studies in developing countries, which revealed that 
the risk of all-cause mortality was significantly associated with multiple failures in a dose-dependent manner, compared to those children who did not have any deficit [7]. Further studies need to be conducted in other therapeutic feeding centers to ascertain the relationship between multiple anthropometric deficits and mortality.

Table 1: Frequency of severe underweight and stunting among less than and more than 2-year-old SAM.

\begin{tabular}{|c|c|c|c|c|}
\hline \multirow[b]{2}{*}{ Total SAM $(n=299)$} & \multicolumn{2}{|c|}{$2-23 m(n=266)$} & \multicolumn{2}{|c|}{$24-59 m(n=33)$} \\
\hline & $\mathbf{n}$ & $\%$ & $\mathbf{n}$ & $\%$ \\
\hline Severe underweight & 200 & 75.2 & 25 & 75.5 \\
\hline Severe stunting & 96 & 36.1 & 17 & 51.5 \\
\hline
\end{tabular}

Table 2: Background characteristics of 6-59 months SAM who died during management.

\begin{tabular}{|c|c|c|c|}
\hline Characteristics & $\begin{array}{c}6-23 \text { months } \\
n=7\end{array}$ & $\begin{array}{c}24-59 \text { months } \\
n=2\end{array}$ & $\begin{array}{c}\text { Total } \\
\mathbf{n}=9(100)\end{array}$ \\
\hline $\begin{array}{l}\text { Co-morbidities } \\
\text { Diarrhea } \\
\text { Bronchopneumonia }\end{array}$ & $\begin{array}{l}7(100.0) \\
0(000.0)\end{array}$ & $\begin{array}{l}1(50.0) \\
1(50.0)\end{array}$ & $\begin{array}{l}8(77.8) \\
1(11.1)\end{array}$ \\
\hline $\begin{array}{c}\text { Anthropometric deficits } \\
\text { Wasting + Underweight } \\
\text { Wasting + Underweight + Stunting }\end{array}$ & $\begin{array}{l}2(28.6) \\
5(71.4)\end{array}$ & $\begin{array}{l}1(50.0) \\
1(50.0)\end{array}$ & $\begin{array}{l}3(33.3) \\
6(66.7)\end{array}$ \\
\hline $\begin{array}{l}\text { Time of death since admission } \\
\text { Less than } 24 \mathrm{hr} \\
\text { 2nd }-3 \text { rd day } \\
4 \text { th }-7 \text { th day }\end{array}$ & $\begin{array}{l}2(28.6) \\
4(57.1) \\
1(14.3)\end{array}$ & $\begin{array}{l}0(000) \\
2(100) \\
0(000)\end{array}$ & $\begin{array}{l}2(22.2) \\
6(66.7) \\
1(11.1)\end{array}$ \\
\hline
\end{tabular}

\section{References}

1. International Food Policy Research Institute (2016) Global nutrition report 2016: from promise to impact: ending malnutrition by 2030 . Washington, USA.

2. http://data.uniceforg/topic/nutrition/malnutrition/

3. Mo PHP, CSO (2015) Yemen National Health and Demographic Survey, 2013, Ministry of Public Health and Population (MoPHP), Central Statistical Organization (CSO), Pan Arab Program for Family Health (PAPFAM), International (ICF) In. Rockville, Maryland, USA.

4. Svedberg P (2003) Poverty and undernutrition: theory, measurement and policy. Oxford Scholarship Online, New York, USA, pp. 189-226.
5. Nandy S, Irving M, Gordon D, Subramanian SV, Smith GD (2005) Poverty, child undernutrition and morbidity: new evidence from India. Bull World Health Organ 83(3):210-216.

6. https://www.who.int/childgrowth/en/

7. McDonald CM, Olofin I, Flaxman S, Fawzi WW, Spiegelman D, et al. (2013) Nutrition Impact Model Study. The effect of multiple anthropometric deficits on child mortality: meta-analysis of individual data in 10 prospective studies from developing countries. Am J Clin Nutr 97(4):896-901. 